\title{
Color and Money: How Rich Kids Are Winning the War Over College Affirmative Action
}

\author{
By Peter Schmidt, Palgrave McMillan, \\ New York, 2007; \\ ISBN: 1-4039-7601-5; 225 pp; US\$24.95
}

International Journal of Educational Advancement (2008) 8, 105-107. doi:10.1057/ijea.2008.12

Color and Money opens with the question, "Who should run our society?" because admissions at selective higher education institutions determines access to power. Americans believe the system judges based on merit, but what if the system did not? As Schmidt says, "This book might not democratize access to selective colleges, but it seeks to at least democratize the debate over who should be gaining admission to such institutions. I have written it to help ordinary people see how the opportunities available to America's children-and our nation's future-are being shaped both by the decisions of elite and by the choices all of us make in the home, the workplace, and the voting booth (p. 11)."

Affirmative action: the phrase itself remains just as much a political controversy today as it did when it was coined by John F. Kennedy in 1961. The historical foundations leading to the current policy ordeal make for a complex argument, but Schmidt integrates stories and interviews with statistics and reports to encompass the full breadth of the issue. His experience covering these issues as a reporter at Education Week, the Associated Press, the Detroit Free Press, and most recently as the deputy editor of the Chronicle of Higher Education further his ability to explain how affirmative action fits into the larger social issues at play in society.

To a great extent, the book covers the historical aspects of the affirmative action debate, from its inception in the 1960s until the publication date in early 2007. While most other discussions of affirmative action stop at the borders of higher education, Schmidt follows the ideas to their source, spanning politics, sociology, $\mathrm{K}-12$ education, and the civil rights movement, to name a few. He also 
realistically portrays the theoretical arguments, research data, and political motivations of the winners and losers in affirmative action policy without regard to political correctness. Literally nothing falls out of bounds for this insightful collection. Schmidt relays that California university students invited David Duke, the Ku Klux Klansman and Louisiana politician, to campus during the debate on proposition 209, in order to present the pro-209 side of the ballot initiative to ban race-based preferences. In addition, nearly every president since the 1960s faced this controversial issue, but none used it as effectively as Ronald Reagan did. He took a stand on affirmative action during his presidency to fuel a Democratic divide, which worked to the Republican advantage on countless occasions and likely motivated the GOP Congressional success in the 1994 elections.

The book includes novel critiques of the arguments both for and against affirmative action. Schmidt describes how lowered admissions standards for legacies, personal contacts, endowment gift providers, and largely Caucasian athletes greatly outnumbers the lowered standards for racial groups, and universities' reluctance to give up the second group for fear of losing the first. In addition, the original affirmative action policies pacified social unrest on college campuses in the 1960s, but have remained intact since then through post-hoc rationalizations for their existence. New explanations for affirmative action include valuing diversity as a government interest, for its educational value, to prepare students for employment in a global economy, or to remedy social injustices. As recent court cases have made clear, research on the topic does not substantiate claims on either side of the issue. The reasons for the policy continually change, although the policy itself remains essentially the same. The very groups these policies established to fight against (the establishment, big business, and colleges and universities) now support them. This further illustrates just how different these current policies and the social atmosphere of today differ from when they came into being.

The book's greatest strength may also hold it back. The comprehensive nature of the book and having to understand the many arguments outside the strictly higher education admissions realm also makes the stories hard to follow. The breadth of information provided, although fully explained, might overwhelm a novice to the issue. I would strongly recommend this book to anyone interested in higher education or the social and political issues facing all Americans, since this controversial issue has not reached its ultimate conclusion. The concepts of the book continue to be relevant to the everyday happenings in higher education institutions and governance. The cynical views of policy activity presented by Schmidt also help to inform critical thinking processes about controversial issues, even outside the domain of higher education.

I find it both rare and refreshing to read such an honest, insightful book, which boldly challenges the status quo. Although it includes a historical review and analysis of the past affirmative action literature, Color and Money will certainly shape future debates on the issue. The public can no longer 
overlook the secrets behind the elite preferences at selective institutions, nor the greater societal concerns of class disparities that affirmative action and race-based differences continue to overshadow. Schmidt artfully makes public the once private information and empowers all Americans to enter the debate on affirmative action.

\section{Christine M. Luce}

Vanderbilt University's Peabody College Nashville, Box 514 GPC, 230 Appleton Place, TN 37203, USA 